\title{
1 The solubility of calcium phosphate in
}

\section{2 concentrated dairy effluent brines}

3 K. Kezia ${ }^{1}$, J. Lee ${ }^{2}$, B. Zisu ${ }^{3}$, G. Q. Chen ${ }^{1}$, S. L. Gras ${ }^{1,4}$, S. E. Kentish ${ }^{1 *}$

4 1. The ARC Dairy Innovation Hub, Department of Chemical \& Biomolecular Engineering,

$5 \quad$ University of Melbourne, Vic 3010 Australia

6 2. Department of Chemical and Process Engineering, University of Surrey Guildford, Surrey

7 GU27XH United Kingdom

8 3. School of Applied Science, College of Science, Engineering and Health, RMIT University

9 Melbourne, Vic 3000 Australia

10 4. The Bio21 Molecular Science and Biotechnology Institute, University of Melbourne, Vic

113010 Australia

12

13 Keywords: calcium phosphate; dairy; brine; solid phase equilibria; lactate; citrate.

14

15 Corresponding Author

16 *Email: sandraek@unimelb.edu.au Phone: +61 383446682 
20 The solubility of calcium phosphate in concentrated dairy brine streams is important in 21 understanding mineral scaling on equipment such as membrane modules, evaporators and 22 heat exchangers, and in brine pond operation. In this study, the solubility of calcium 23 phosphate has been assessed in the presence of up to $300 \mathrm{~g} / \mathrm{L}$ sodium chloride as well as 24 lactose, organic acids and anions at $10^{\circ} \mathrm{C}, 30^{\circ} \mathrm{C}$ and $50^{\circ} \mathrm{C}$. As a neutral molecule, lactose has a 25 marginal, but still detectable effect upon calcium solubility. However, additions of sodium 26 chloride up to $100 \mathrm{~g} / \mathrm{L}$ result in a much greater increase in calcium solubility. Beyond this

27 point, the concentrations of ions in the solution decreases significantly. These changes in 28 calcium solubility can readily be explained through changes in the activity coefficients. There 29 is little difference in calcium phosphate speciation between 10 and $30^{\circ} \mathrm{C}$. However, at $50^{\circ} \mathrm{C}$, 30 the ratio of calcium to phosphate in the solution is lower than at the other temperatures and 31 varies less with ionic strength. While the addition of sodium lactate has less effect upon 32 calcium solubility than sodium citrate, it still has a greater effect than sodium chloride at an 33 equivalent ionic strength. Conversely, when these organic anions are present in the solution 34 in the acid form, the effect of $\mathrm{pH}$ dominates and results in much higher solubility and a 35 calcium/phosphate ratio close to one, indicative of dicalcium phosphate dihydrate as the 36 dominant solid phase. 
39 With increasingly stringent environmental regulation, dairy industries in Australia are under 40 pressure to pretreat saline effluent so as to improve the quality and reduce the volume of 41 discharged effluent. This effluent stream comprises small amounts of milk sugar, large 42 concentrations of sodium chloride $(\mathrm{NaCl})$ from cheese manufacturing plants, as well as 43 smaller amounts of divalent salts such as calcium phosphates. Due to the low economic value 44 of the discharged effluent, any concentration process should be performed at minimum cost. Such processes are commonly conducted by membrane filtration or thermal evaporation. During the concentration process, heterogenous precipitation of minerals on the surface of evaporators or membrane modules often occurs, creating a major fouling issue and reducing the lifetime of the equipment. If the salt concentration exceeds the limits set by local water authorities, it may then be necessary to divert the saline effluent to a brine pond, where further precipitation occurs.

The primary precipitating agent is calcium phosphate, which possesses low solubility in comparison to sodium chloride or lactose. Studies of the solubility of calcium phosphate are complex and ongoing, due to incongruent dissolution phenomenon and dynamic intermediate equilibria ${ }^{1-4}$. Calcium phosphate is a biomineral, which can exhibit various forms with different ratios of calcium to phosphate. The solubility of calcium phosphate is also affected by $\mathrm{pH}$, temperature, the presence of ionic impurities and their concentration, the total ionic strength and the precipitation rate ${ }^{5,6}$. Compared to the other parameters, $\mathrm{pH}$ has the most profound effect and has been extensively studied ${ }^{7-9}$.

The solubility of different calcium phosphate compounds across variable $\mathrm{pH}$ ranges are listed

60 in Table 1 . In cheese whey where the $\mathrm{pH}$ is typically $4-5$, dicalcium phosphate dihydrate

61 (DCPD) is the most common precipitant. At higher $\mathrm{pH}$, salts such as octacalcium phosphate 
62 (OCP) or hydroxyapatite (HAP) are more thermodynamically stable (Table 1). However in dairy processing, DCPD often remains dominant. This is usually attributed to faster crystallization kinetics for DCPD ${ }^{10} 11,12$. Inhibition of HAP and subsequent formation of DCPD has also been attributed to the presence of citrates in these dairy systems ${ }^{13,14}$.

66 At room temperature, phosphoric acid dissociates based on the $\mathrm{pH}$ of the environment, as

67 shown below ${ }^{15}$. This ionization governs the cation pairing mechanism to maintain electro68 neutrality within the solution.

$\mathrm{H}_{3} \mathrm{PO}_{4} \leftrightarrow \mathrm{H}^{+}+\mathrm{H}_{2} \mathrm{PO}_{4}^{-} \quad p K_{1}=2.1$

$\mathrm{H}_{2} \mathrm{PO}_{4}^{-} \leftrightarrow \mathrm{H}^{+}+\mathrm{HPO}_{4}{ }^{2-} \quad p K_{2}=7.2$

$\mathrm{HPO}_{4}{ }^{2-} \leftrightarrow \mathrm{H}^{+}+\mathrm{PO}_{4}{ }^{3-} \quad p K_{3}=12.3$

72 In dairy systems such as saline effluent and salty whey permeate, the solubility is also greatly affected by the presence of background electrolytes. In particular, high concentrations of

$\mathrm{NaCl}$ and organic anions such as lactate and citrate are often present. For example, in a saline effluent such as salty whey permeate, the concentration of citrate ranges from $0.8 \mathrm{mM}$ to 3.6 $\mathrm{mM}$. Citrate is known to sequester calcium to form the soluble calcium citrate anion $\left(\mathrm{CaCit}^{-}\right)$, which increases calcium solubility ${ }^{16,17}$. In fresh salty whey permeate, lactate concentration can vary from $1.6 \mathrm{mM}$ to $37 \mathrm{mM}$. This lactate concentration can further increase with time due to the action of residual lactic acid bacteria which convert lactose into this acid. Indeed, we have observed lactate concentrations of over $100 \mathrm{mM}$ for samples stored in our laboratory

81 for six months.

82 The initial amount of $\mathrm{NaCl}$ can range between $30 \mathrm{~g} / \mathrm{L}$ to $100 \mathrm{~g} / \mathrm{L}(0.5-1.7 \mathrm{M})$ and this could 83 be concentrated up to an equivalent of $250-300 \mathrm{~g} / \mathrm{L}(>4-5.1 \mathrm{M})$ during effluent treatment. 84 Similarly, the calcium concentration might start at 40mM (7 g/L DCPD) but increase to 120 
$85 \mathrm{mM}(20 \mathrm{~g} / \mathrm{L}$ DCPD $)$ during concentration ${ }^{18}$. Further, process temperatures can swing between

86 production and effluent treatment steps, ranging from $4^{\circ} \mathrm{C}$ to greater than $50^{\circ} \mathrm{C}$. There is

87 currently little information regarding the solubility and precipitation behavior of calcium

88 phosphate under such operating conditions.

89 The current study aims to deepen our understanding of these processes and to assess the

90 possibility for selective precipitation of calcium phosphate salt. To achieve this objective, we

91 mimic the impurities and ionic strength of saline effluent in a full-scale system.

92 Understanding the precipitation of calcium phosphate in the presence of extreme

93 concentrations of $\mathrm{NaCl}$ and organic anions and acids will aid in mitigating mineral scaling

94 and thus prolong the lifetime of equipment through the adjustment of operating conditions.

95 These findings have applications beyond the treatment of dairy saline effluent, encompassing

96 water treatment processes within other chemical industries. 


\section{Materials}

100 All chemicals used were analytical grade and were used as received without further 101 purification. For experiments and cleaning procedures, purified water (Elix Millipore, resistivity $>15 \mathrm{M} \Omega \mathrm{cm}-1$ ) was used. For analytical procedures and preparation of standard solutions, water of higher purity (Milli-Q Millipore, resistivity $>18 \mathrm{M} \Omega \mathrm{cm}-1$ ) was used.

104 Dicalcium phosphate dihydrate, DCPD $\left(\mathrm{CaHPO}_{4} .2 \mathrm{H}_{2} \mathrm{O},>98 \%\right)$ was obtained from Astral

105 Scientific. Calcium chloride dihydrate $\left(\mathrm{CaCl}_{2} .2 \mathrm{H}_{2} \mathrm{O},>99 \%\right)$, di-Sodium hydrogen phosphate $106\left(\mathrm{Na}_{2} \mathrm{HPO}_{4},>99 \%\right)$ and lactose monohydrate $\left(\mathrm{C}_{12} \mathrm{H}_{22} \mathrm{O}_{11} \cdot \mathrm{H}_{2} \mathrm{O}\right)$ were purchased from Chem 107 Supply. To adjust the $\mathrm{pH}$ and organic anion concentration, tri-sodium citrate ( $\left.\mathrm{Na}_{3} \mathrm{Cit},>99 \%\right)$, sodium lactate $\left(\mathrm{NaC}_{3} \mathrm{H}_{5} \mathrm{O}_{3},>70 \%\right)$, citric acid $\left(\mathrm{C}_{6} \mathrm{H}_{8} \mathrm{O}_{7},>99 \%\right)$ and lactic acid $\left(\mathrm{C}_{3} \mathrm{H}_{6} \mathrm{O}_{3}\right.$, $85 \%)$ were purchased from Chem Supply and nitric acid $\left(\mathrm{HNO}_{3}, 69.5 \%\right)$ was purchased from

110 Scharlau.

\section{$111 \quad$ Methods}

112 The experiments were performed using an end-point equilibrium technique. This technique

113 operates by incubating excess amounts of solid in a pre-conditioned background solution at 114 constant temperature. It has been widely utilized for solubility measurement ${ }^{19}$. In the present 115 case, a consistent excess amount (2 g unless otherwise stated) of solid DCPD $(\mathrm{Ca} / \mathrm{P}=1)$ was 116 added to $200 \mathrm{ml}$ of a background solution in a glass container, as shown in Figure 1 . The

117 composition of the background solution was adjusted to be between $0-300 \mathrm{~g} / \mathrm{L}(5.1 \mathrm{M})$

$118 \mathrm{NaCl}$ and 0 to $100 \mathrm{~g} / \mathrm{L}(0.3 \mathrm{M})$ of lactose. The role of organic acid and anions was determined 119 using a background solution of 1 to $100 \mathrm{mM}$ of either lactic or citric acid, sodium lactate or 120 sodium citrate. The vessel was double-sealed using Parafilm M,R Laboratory film (SPI 
121 supplies) and capped to avoid evaporation. It was then incubated in a circulating water bath

122 (Julabo) controlled at $10^{\circ} \mathrm{C}, 30^{\circ} \mathrm{C}$ or $50^{\circ} \mathrm{C}$ for 168 hours (one week). A constant stirring rate

123 was set at approximately $250 \mathrm{rpm}$. At the end of the incubation period, the supernatant was

124 filtered using a $0.2 \mu \mathrm{m}$ (polyethersulfone, PES) syringe filter (Millipore) and the composition

125 of the supernatant liquor was analysed. The $\mathrm{pH}$ was measured at the beginning and at the end

126 of the experiment, using a WP81 double junction glass $\mathrm{pH}$ electrode and temperature probe, connected to a digital benchtop meter. Each experiment was carried out at least in duplicate.

128 At the conclusion of experiments, the concentration of $\mathrm{Ca}, \mathrm{Na}$ and phosphorus (P) was measured using Inductively Coupled Plasma - Optical Emission Spectrometry (ICP-OES)

130 (Varian 720-OES). The concentrations of the orthophosphate anions $\left(\mathrm{H}_{2} \mathrm{PO}_{4}^{-}, \mathrm{HPO}_{4}{ }^{2-}, \mathrm{PO}_{4}{ }^{3-}\right)$ 131 and chloride $\left(\mathrm{Cl}^{-}\right)$were determined using Ion Chromatography (Dionex 1000CS) with an AS

13214 anion exchange column. The concentration of lactate and citrate was quantified using 133 Reverse Phase High Performance Liquid Chromatography (RP-HPLC) (Shimadzu LC-20AT) 134 employing an ion-exchange column (HPX-87H). Triplicate measurements were performed 135 for each independent sample and the error margins are based on a single standard deviation of 136 these results $(n=6)$. Data was analysed using one way analysis of variance (ANOVA), with a 137 significance level of $\mathrm{p}=0.01$.

138 The behavior of calcium and phosphate ions in the solution was also simulated through 139 predictions of the activity coefficient of these ions at ionic strengths of 0 to $5 \mathrm{M} \mathrm{NaCl}$. 140 ASPEN Plus V8.6 (Aspen One) was employed using the Pitzer thermodynamic package. 


\section{RESULTS AND DISCUSSION}

\section{Effect of neutral solute (lactose)}

144 It was expected that lactose would not alter the solubility of calcium phosphate, as a neutral

145 solute should not dictate ion speciation phenomena. However, there was a significant increase

$146(\mathrm{p}<0.01)$ in the concentration of soluble calcium from $0.68 \pm 0.06 \mathrm{mM}$ to $1.33 \pm 0.10 \mathrm{mM}$,

147 as the lactose concentration increased from 0 to $100 \mathrm{~g} / \mathrm{L}$ (Figure 2). It can also be seen from

148 Figure $2 \mathrm{~b}$ that the calcium to phosphate ratio $(\mathrm{Ca} / \mathrm{P})$ in the supernatant in the absence of

149 lactose or $\mathrm{NaCl}$ is significantly less than unity $(\mathrm{p}<0.01)$, indicating that the solid phase has a

$150 \mathrm{Ca} / \mathrm{P}$ ratio greater than unity, indicative of significant quantities of HAP or OCP (Table 1).

151 As the amount of the remaining excess solid in the solution is significantly greater than the

152 amount dissolved, an accurate mass balance of the solid could not be conducted to confirm

153 the exact solid phase composition.

154 Increasing the lactose concentration significantly increases $(\mathrm{p}<0.01)$ the $\mathrm{Ca} / \mathrm{P}$ ratio, from

$1550.54 \pm 0.01$ to $0.70 \pm 0.01 \mathrm{mM}$. The effect of sugars on different calcium salts has also been

156 observed by Doherty et al. ${ }^{20}$ in a calcium oxalate-sucrose system. Besic ${ }^{21}$ claims that

157 sucrose in food products affects the solubility of calcium and phosphate in teeth. Other

158 workers have shown that calcium salts can significantly influence the solubility and growth

159 rate of lactose crystals due to the formation of a lactose complex ${ }^{22,23}$. The changing

160 solubility may also reflect a decrease in the water activity as the lactose concentration

161 increased, consistent with the observation of a very small conductivity increase. However,

162 while lactose clearly impacts calcium solubility, the effect is very small, when compared with

$163 \mathrm{NaCl}$, as also seen in Figure 2(a). The remainder of this work therefore focuses on the impact

164 of such ionic species. 


\section{Effect of ionic strength}

167 It can be seen from Figure 3 that the concentration of the calcium ion in the supernatant 168 increases significantly for all temperatures as the $\mathrm{NaCl}$ concentration increases to $100 \mathrm{~g} / \mathrm{L}$.

169 Beyond this point, a significant $(\mathrm{p}<0.01)$ decrease in both the soluble calcium and phosphate

170 concentration is observed. This decreased solubility of calcium in solution at the highest

$171 \mathrm{NaCl}$ concentrations is of significance in understanding fouling in equipment such as brine

172 evaporators, which may operate under such conditions. The decreased solubility could cause rapid calcium scaling to occur.

174 These trends in solubility can be understood by reference to the activity coefficient of the ions in solution. With increasing ionic strength, the activity coefficient of both calcium and

176 phosphate ions decrease (Figure 4) resulting in increased solubility. This loss in activity 177 results from ion-pairing (association), which has been previously investigated ${ }^{24-26}$, up to the

178 ionic strength of seawater (approximately $35 \mathrm{~g} / \mathrm{L}$ or $0.7 \mathrm{M}$ ) at room temperature. Millero et $179 \mathrm{al}^{26}$ uses the Pitzer equation to predict that the activity coefficient of $\mathrm{Ca}^{2+}$ should decrease 180 from 0.851 at an ionic strength of $0.002 \mathrm{M}$ down to 0.225 at an ionic strength of $0.7 \mathrm{M}$ at 25

$181{ }^{\circ} \mathrm{C}$. Their study also predicts that the activity coefficients for $\mathrm{H}_{2} \mathrm{PO}_{4}^{-}$decrease from 0.947 to 1820.363 and for $\mathrm{HPO}_{4}{ }^{2-}$ from 0.758 to 0.044 . Comparable values were generated in the present 183 case, as shown in Figure 4. However, beyond a salt concentration of $100 \mathrm{~g} / \mathrm{L}$ the activity coefficients for calcium increase again.

Prediction of the supernatant concentration using these activity coefficients is a complex problem given the solid phase equilibria between OCP, HAP and DCPD, in addition to the

187 phosphate speciation given by Equations 1 to 3 . Figure 5 shows a simulation for the simplest 188 case where DPCD is assumed to be the only solid phase, using the solubility constant 189 provided in Table 1 at $25^{\circ} \mathrm{C}$. It is clear that even this simple simulation provides a reasonable 
190 fit to the supernatant calcium concentration. The phosphate concentrations are higher, again suggesting that the solid phase contains OCP or HAP in addition to DCPD.

192 With increasing ionic strength a small decrease in $\mathrm{pH}$ was observed. The $\mathrm{pH}$ fell from 7.67 $193 \pm 0.25$ in the absence of $\mathrm{NaCl}$ to $7.00 \pm 0.22$ at $300 \mathrm{~g} / \mathrm{L} \mathrm{NaCl}$. At comparable $\mathrm{pH}$ values and 194 at zero $\mathrm{NaCl}$ concentration, the $\mathrm{Ca} / \mathrm{P}$ ratio observed (Table 2 ) is similar to the value reported 195 by Sutter et al. from their leaching experiments ${ }^{27}$. However, with increasing ionic strength, 196 the $\mathrm{Ca} / \mathrm{P}$ ratio increases significantly at both $10{ }^{\circ} \mathrm{C}$ and $30{ }^{\circ} \mathrm{C}$, with values in the range of $1970.72-0.77$ at 10 to $300 \mathrm{~g} / \mathrm{L} \mathrm{NaCl}$. This suggests a shift back from OCP or HAP towards 198 DCPD, consistent with the common observations in dairy processing. Conversely, there is no 199 significant shift in the $\mathrm{Ca} / \mathrm{P}$ ratio at $50^{\circ} \mathrm{C}$, implying that at this temperature, the crystal 200 morphology is unaffected by ionic strength. Figure 4(b) also shows that the ionic strength 201 affects the activity of $\mathrm{H}_{2} \mathrm{PO}_{4}^{-}, \mathrm{HPO}_{4}{ }^{2-}$ and $\mathrm{PO}_{4}{ }^{3-}$ to differing extents, which alters the 202 equilibria of these species. These changes may also explain the observed $\mathrm{pH}$ variation.

204 Some workers have argued that the amount of excess solid existing in the system alters the solubility of calcium phosphate, with the lowest solubility occurring for the smallest amount of solid ${ }^{1,28,29}$. This is consistent with the present results shown in Figure 6. In the absence of

$207 \mathrm{NaCl}$, no significant difference could be observed $(\mathrm{p}<0.01)$, as the amount of $\left[\mathrm{Ca}^{2+}\right]$ 208 dissolved in the solution is very low. However, at higher ionic strength, it can be seen that the solubility is significantly affected $(\mathrm{p}<0.01)$ by the amount of remaining excess solid in the solution. These differences have been reported to relate to the different calcium phosphate

211 polymorphs that can form and the resulting equilibria between multiple solid phases, in 212 addition to the liquid-solid phase equilibria. These authors argue that this is the reason that 213 the solubility data reported by researchers using different techniques often shows wide variability. 


\section{Effect of Temperature}

217 The solubility of both calcium and phosphate is identical within experimental error at $10{ }^{\circ} \mathrm{C}$ 218 to $30{ }^{\circ} \mathrm{C}$ for $\mathrm{NaCl}$ concentrations of up to $50 \mathrm{~g} / \mathrm{L}$ (Figure 3). However, beyond this 219 concentration, the solubility at $30^{\circ} \mathrm{C}$ is significantly lower than that at $10^{\circ} \mathrm{C}(\mathrm{p}<0.01)$. 220 Changes in solubility with temperature are more apparent at $50^{\circ} \mathrm{C}$, with the solubility 221 increasing significantly $(\mathrm{p}<0.01)$ at all $\mathrm{NaCl}$ concentrations. Sutter et al. ${ }^{27}$ observed a slight 222 decrease in the concentration of soluble calcium in the solution from temperatures of $5{ }^{\circ} \mathrm{C}$ to $223 \quad 37{ }^{\circ} \mathrm{C}$ using a leaching technique (at comparable $\mathrm{pH} \sim 6.5-6.8$ ) and from $25^{\circ} \mathrm{C}$ to $37^{\circ} \mathrm{C}$ in 224 batch experiments at near neutral and acidic conditions. On the other hand, Green and Perry 30 report an increasing solubility of monobasic calcium phosphate with respect to temperature. These literature results are all broadly consistent with the work presented here.

227 However, the temperature effects in this case should not be oversimplified as the $\mathrm{Ca} / \mathrm{P}$ ratio in the solution is also significantly altered, especially at $50{ }^{\circ} \mathrm{C}$ where this ratio decreases to 0.45

$229 \pm 0.05$ (Table 2).

230 The results appear initially inconsistent with many previous studies, which claim that calcium

231 phosphate solubility declines with temperature ${ }^{31-33}$. Indeed, in our own work, we have also 232 previously observed that increasing the temperature could shorten the time it takes for the 233 first appearance of crystals in saline dairy effluent ${ }^{34}$. However, these references generally describe kinetic effects, where increasing temperature causes calcium salts to precipitate in a shorter time. The present work and that of the literature cited above considers the final equilibrium after at least 168 hours, where such kinetic effects become irrelevant. 


\section{Effect of Organic anions}

240 Figure 6 shows the concentration of calcium in the solution in the presence of either the

241 organic lactic and citric acids, or the strong acid $\mathrm{HNO}_{3}$. The increasing solubility of calcium

242 phosphate with respect to $\mathrm{pH}$ is well known $(\mathrm{pH}<6)$, although this effect varies depending

243 upon the $\mathrm{pKa}$ of the specific acid. The role of $\mathrm{pH}$ in governing the solubility of calcium

244 phosphate salts by addition of orthophosporic acid has been reported ${ }^{35,36}$. However,

245 orthophosphoric acid exhibits both weak acid and polybasic properties, and will alter the

246 amount of available phosphate in the solution through the common ion effect. In this study,

$247 \mathrm{HNO}_{3}$ is used to isolate the role of $\mathrm{pH}$, as the formation of $\mathrm{Ca}\left(\mathrm{NO}_{3}\right)_{2}$ is unlikely to occur.

248 In $1 \mathrm{mM} \mathrm{HNO}_{3}$, lactic acid or citric acid, the initial $\mathrm{pH}$ of the solution (with $20 \mathrm{~g} / \mathrm{L} \mathrm{DCPD)}$

249 is $4.61 \pm 0.14,5.67 \pm 0.38$ and $5.00 \pm 0.33$, respectively. Within this $\mathrm{pH}$ range the

250 concentration of calcium recorded in solution is comparable to the value reported by Sutter et

251 al. ${ }^{27}$ obtained using a leaching method where the $\mathrm{pH}$ was adjusted using $\mathrm{H}_{3} \mathrm{PO}_{4}$. The values recorded at $1 \mathrm{mM}$ are also comparable with that obtained by other workers using OCP as the starting solid ${ }^{37}$. The calcium solubility is lowest for the lactic acid $(\mathrm{p}<0.01)$, reflecting its weak acidity and hence the relatively high $\mathrm{pH}$ of the solution. The solubility of the nitric and citric acids are comparable within experimental error, even though the $\mathrm{pH}$ of the citric solution is higher than that of the nitric. This reflects the calcium sequestering capacity of the citrate anion.

Discrepancies with the literature are observed at higher acidity (10 mM, see Figure 7$)$. The solubility of calcium in the solution is two to four times lower compared to the concentration reported by Sutter et al. ${ }^{27}$. At the end of experiments, these workers obtain a value of $47 \mathrm{mM}$ at similar $\mathrm{pH}\left(\mathrm{pH} 2.90\right.$ and 3.53 for $\mathrm{HNO}_{3}$ and lactic acid respectively in this work, versus 
2623.38 in the Sutter et al. study). This might be due to the utilisation of different acids here instead of orthophosphoric acid.

Figure $8 \mathrm{a}$ shows that the solubility of calcium ions increases significantly $(\mathrm{p}<0.01)$ as the sodium lactate concentration increases from 1 to $100 \mathrm{mM}$ at 10 and $30{ }^{\circ} \mathrm{C}$. The use of sodium lactate in these experiments ensures that the $\mathrm{pH}$ of the solution changes little, within the range of $\mathrm{pH} 7.0$ to 8.7 . The increased solubility is partly associated with the increase in the background ionic strength. Nevertheless, the effect of sodium lactate on the solubility of calcium and phosphate is more pronounced than $\mathrm{NaCl}$ at an equivalent concentration. Specifically, the effect of $100 \mathrm{mM}$ sodium lactate on calcium solubility is equivalent $(\mathrm{p}>0.05)$ to $170 \mathrm{mM}(10 \mathrm{~g} / \mathrm{L})$ of $\mathrm{NaCl}$ at $10^{\circ} \mathrm{C}$ and $30^{\circ} \mathrm{C}$ (see Table 3$)$. different calcium phosphate speciation is occurring. The calcium solubility increases further, but it is difficult to confirm whether this is due to the lactate or the shift in $\mathrm{pH}$.

In dairy effluent, the amount of citrate is relatively low compared to lactate. However, much greater increases in the concentration of calcium in the solution are observed when the citrate anion is added to solution (Figure 8a). The contribution of $\mathrm{pH}$ is again minimized here through utilization of tri-sodium citrate $(\mathrm{pH}$ 7.3-8.2). It is clear that citrate shows a strong calcium sequestering capacity, as has been widely reported elsewhere ${ }^{4,35,38-43}$. The effect of temperature on the saturation concentration of calcium in the presence of the citrate anion is

281 less clear than with lactate or chloride, due to the dominant effect of citrate sequestration 282 (Figure 8a).

A steady increase in the calcium concentration in the solution is observed for both organic acids as shown in Figure $8 \mathrm{~b}$. The sequestering capacity of citrate dominates over the contribution of $\mathrm{pH}$ under all conditions, with the total calcium in the citric acid solution three 
to four times higher than in lactic acid. Further, analysis indicated that after 168 hours equilibration, from an initial concentration of $10 \mathrm{mM}$ of organic acid, $5.4 \pm 0.8 \mathrm{mM}$ of citrate was consumed whereas only $1.5 \pm 0.3 \mathrm{mM}$ lactate was consumed for the same amount of DCPD. At $100 \mathrm{mM}$ (Figure 6), the concentration of calcium in the solution is largely the same for lactic and nitric acid, which confirms that the increase in solubility for lactic acid is solely due to phosphate dissociation at these extreme $\mathrm{pH}$ levels (DCPD in $100 \mathrm{mM} \mathrm{HNO} \mathrm{H}_{3} \mathrm{pH}$ 1.75 and in $100 \mathrm{mM}$ lactic acid $\mathrm{pH} 2.68)$.

The addition of sodium lactate has minimal impact on the $\mathrm{Ca} / \mathrm{P}$ ratio at $30^{\circ} \mathrm{C}$ (see Figure 9 ).

Conversely, the addition of trisodium citrate increases the amount of the available calcium in the solution due either to formation of $\mathrm{CaCit}^{-}$or to the preferential formation of DCPD ${ }^{13,14}$. The addition of lactic acid causes the $\mathrm{Ca} / \mathrm{P}$ ratio to increase to unity. This is consistent with the literature; DCPD is the most stable salt at $\mathrm{pH}$ less than 5.5 (Table 1). A similar increase was expected for citric acid, however this was not clearly observed, with the $\mathrm{Ca} / \mathrm{P}$ in this case showing significant variability (data not shown).

As with the systems containing $\mathrm{NaCl}$ (Table 2) in systems at neutral $\mathrm{pH}$, high temperature $\left(50{ }^{\circ} \mathrm{C}\right)$ results in a lower $\mathrm{Ca} / \mathrm{P}$ ratio in solution $(\mathrm{p}<0.01)$ implying preferential formation of HAP or OCP (Table 4). In the presence of lactic acid, the $\mathrm{Ca} / \mathrm{P}$ ratio remains close to unity regardless of the temperature. This shows the dominating effect of $\mathrm{pH}$ in comparison to other parameters. Conversely, with citric acid, this ratio falls with temperature $(p<0.01)$.

\section{Effect of high ionic strength in the presence of lactic acid}

307 In real saline waste effluent, the background electrolyte comprises a mixture of ions. Figure 
acid at $30{ }^{\circ} \mathrm{C}$. The $\mathrm{pH}$ range throughout the whole experiment was $3.7 \pm 0.6$. It can be seen that the trends in solubility observed with $\mathrm{NaCl}$ alone (Figure 3) are no longer observed.

311 Instead, the concentration of calcium in the solution remains relatively constant at the same

312 value as for $10 \mathrm{mM}$ lactic acid alone $(7 \mathrm{mM})$. This again reflects the stronger influence of $\mathrm{pH}$,

313 relative to those of ionic strength alone.

314 Despite the dominance of $\mathrm{pH}$ in determining the calcium solubility, the presence of $\mathrm{NaCl}$

315 still significantly affects the $\mathrm{Ca} / \mathrm{P}$ ratio. In the absence of $\mathrm{NaCl}$, the $\mathrm{Ca} / \mathrm{P}$ ratio observed is $3161.01 \pm 0.03$ which is consistent with the $\mathrm{Ca} / \mathrm{P}$ ratio across a broad range of acidic conditions.

317 However, in the presence of $\mathrm{NaCl}$ the $\mathrm{Ca} / \mathrm{P}$ ratio falls significantly $(\mathrm{p}<0.01)$ to $0.8 \pm 0.03$.

In this work, the solubility of calcium phosphate in the presence of high concentrations of lactose, sodium chloride, lactate and citrate and under conditions of variable acidity and temperature has been investigated. Lactose has a marginal but significant effect upon the saturation concentration of calcium in the solution, possibly due to the formation of a complex of lactose with calcium salts. Increasing ionic strength through the addition of $\mathrm{NaCl}$ up to $100 \mathrm{~g} / \mathrm{L}$ within the temperature range of $10^{\circ} \mathrm{C}$ to $50^{\circ} \mathrm{C}$, reduces the activity of $\mathrm{Ca}^{2+}$ resulting in an increase of calcium in the solution. Above this $\mathrm{NaCl}$ concentration, the calcium solubility declines, particularly at $50^{\circ} \mathrm{C}$. This latter finding is of importance in understanding calcium scaling in high salt solutions. The addition of salts such as sodium chloride or trisodium lactate has differing effects on the solubility of $\mathrm{H}_{2} \mathrm{PO}_{4}{ }^{-}$and $\mathrm{HPO}_{4}{ }^{2-}$ at different temperatures, so that at 10 and $30^{\circ} \mathrm{C}$, the $\mathrm{Ca} / \mathrm{P}$ ratio increases from around 0.5 to 0.7-0.8, while at $50^{\circ} \mathrm{C}$ this ratio remains low.

331 The lactate anion shows only a very small calcium sequestering capacity compared to the 332 citrate anion, but is still a more effective sequestering agent than chloride. Specifically, at 
$33310^{\circ} \mathrm{C}$ and $30^{\circ} \mathrm{C}$, the same calcium solubility is achieved by $100 \mathrm{mM}$ sodium lactate as 170

$334 \mathrm{mM}$ sodium chloride. However, when lactate is added as an organic acid, the role of $\mathrm{pH}$

335 dominates, providing large increases in the calcium concentration and resulting in the $\mathrm{Ca} / \mathrm{P}$

336 ratio reaching unity.

337 In a real effluent solution comprising an abundant amount of both $\mathrm{NaCl}$ and lactic acid, the

338 effect of $\mathrm{pH}$ dominates the saturation concentration of calcium, but crystal morphology is still

339 affected by the $\mathrm{NaCl}$ concentration, as indicated by changes in the $\mathrm{Ca} / \mathrm{P}$ ratio.

340 Lastly, experiments showed some evidence in support of previous work by other authors

341 that have suggested that calcium solubility can be affected by the quantity of excess solid in

342 the solution.

343

344

\section{ACKNOWLEDGMENTS}

345 This research was supported under Australian Research Council's Industrial

346 Transformation Research Program (ITRP) funding scheme (Project number IH120100005).

347 The ARC Dairy Innovation Hub is a collaboration between The University of Melbourne,

348 The University of Queensland and Dairy Innovation Australia Ltd. Judy Lee acknowledges

349 the support from an Australian Research Council Discovery Early Career Researcher Award

350 (DE120101567).

352 REFERENCES

353 1. Pan, H. B.; Darvell, B. W., Calcium Phosphate Solubility: The Need for Re-

354 Evaluation. Cryst. Growth Des. 2009, 9, 639-645.

$355 \quad 2 . \quad$ Miyazaki, T.; Sivaprakasam, K.; Tantry, J.; Suryanarayanan, R., Physical

356 characterization of dibasic calcium phosphate dihydrate and anhydrate. J. Pharm. Sci. 2009, $35798,905-916$.

358 3. Pan, H. B.; Darvell, B. W., Solubility of Dicalcium Phosphate Dihydrate by Solid

359 Titration. Caries Res. 2009, 43, 254-260. 
$360 \quad 4 . \quad$ Spanos, N.; Patis, A.; Kanellopoulou, D.; Andritsos, N.; Koutsoukos, P., Precipitation

361 of calcium phosphate from simulated milk ultrafiltrate solutions. Cryst. Growth Des. 2007, 7, 25-29.

363 5. Dorozhkin, S., Calcium Orthophosphates: Occurrence, Properties and Major

364 Applications. Bioceram. Dev. Appl. 2014, 4, 2.

$365 \quad 6 . \quad$ Wang, L.; Nancollas, G. H., Calcium orthophosphates: crystallization and dissolution.

366 Chem. Rev. 2008, 108, 4628-4669.

367 7. Johnsson, M. S.-A.; Nancollas, G. H., The Role of Brushite and Octacalcium

368 Phosphate in Apatite Formation. Crit. Rev. Oral Biol. \& Med. 1992, 3, 61-82.

369 8. Lundager Madsen, H. E.; Thorvardarson, G., Precipitation of calcium phosphate from 370 moderately acid solution. J. Cryst. Growth 1984, 66, 369-376.

$3719 . \quad$ Madsen, H. E. L.; Christensson, F., Precipitation of calcium phosphate at $40 \mathrm{C}$ from

372 neutral solution. J. Cryst. Growth 1991, 114, 613-618.

373 10. Ferreira, A.; Oliveira, C.; Rocha, F., The different phases in the precipitation of

374 dicalcium phosphate dihydrate. J. Cryst. Growth 2003, 252, 599-611.

375 11. House, W. A., The physico-chemical conditions for the precipitation of phosphate

376 with calcium. Environ. Technol. 1999, 20, 727-733.

377 12. Van Kemenade, M.; De Bruyn, P., A kinetic study of precipitation from

378 supersaturated calcium phosphate solutions. J. Colloid Interface Sci. 1987, 118, 564-585.

379 13. Rosmaninho, R.; Melo, L. F., The effect of citrate on calcium phosphate deposition

380 from simulated milk ultrafiltrate (SMUF) solution. J. Food Eng. 2006, 73, 379-387.

381 14. Van Der Houwen, J. A. M.; Valsami-Jones, E., The Application of Calcium

382 Phosphate Precipitation Chemistry to Phosphorus Recovery: The Influence of Organic

383 Ligands. Environ. Technol. 2001, 22, 1325-1335.

384 15. CRC Handbook of Chemistry and Physics. 58th ed.; CRC Press: Cleveland Ohio, 1978.

16. Mekmene, O.; Gaucheron, F., Determination of calcium-binding constants of caseins, phosphoserine, citrate and pyrophosphate: A modelling approach using free calcium measurement. Food Chem. 2011, 127, 676-682.

17. Sharma, V. K.; Johnsson, M.; Sallis, J. D.; Nancollas, G. H., Influence of citrate and phosphocitrate on the crystallization of octacalcium phosphate. Langmuir 1992, 8, 676-679. 18. Kezia, K.; Lee, J.; Weeks, M.; Kentish, S., Direct contact membrane distillation for the concentration of saline dairy effluent. Water Res. 2015.

19. Goss, S. L.; Lemons, K. A.; Kerstetter, J. E.; Bogner, R. H., Determination of calcium salt solubility with changes in $\mathrm{pH}$ and $\mathrm{PCO} 2$, simulating varying gastrointestinal environments. J. Pharm. Pharmacol. 2007, 59, 1485-1492.

20. Doherty, W.; Wright, P. A solubility model for calcium oxalate formation in a sugar mill, in Proceedings-Australian Society Of Sugar Cane Technologists, 2004; PK Editorial Services; 1999: 2004; pp 50.

21. Besic, F. C., Food materials for prevention of carious degradation of teeth.United States Patent No. 4515770 A 1985.

401 22. Jelen, P.; Coulter, S. T., Effects Of Certain Salts And Other Whey Substances On The 402 Growth Of Lactose Crystals. J. Food Sci. 1973, 38, 1186-1189.

403 23. Jensen, O.; Hanford, Z.; Supplee, G., Equilibrium solutions of certain lactose-salt 404 mixtures. J. Dairy Sci. 1940, 23, 745-753.

405 24. Atlas, E.; Culberson, C.; Pytkowicz, R., Phosphate association with $\mathrm{Na}^{+}, \mathrm{Ca}^{2+}$ and $406 \mathrm{Mg}^{2+}$ in seawater. Marine Chem. 1976, 4, 243-254.

407 25. Kester, D. R.; Pytkowicz, R. M., Theoretical model for the formation of ion-pairs in 408 seawater. Marine Chem. 1975, 3, 365-374. 
409

410

411

412

413

414

415

416

417

418

419

420

421

422

423

424

425

426

427

428

429

430

431

432

433

434

435

436

437

438

439

440

441

442

443

444

445

446

447

448

449

450

451

452

453

26. Millero, F. J.; Schreiber, D., Use of the ion pairing model to estimate activity coefficients of the ionic components of natural waters. Am. J. Sci. 1982, 282, 1508-1540. 27. Sutter, J.; McDowell, H.; Brown, W. E., Solubility study of calcium hydrogen phosphate. Ion-pair formation. Inorg. Chem. 1971, 10, 1638-1643.

28. Greenwald, I., The solubility of calcium phosphate I. The effect of $\mathrm{pH}$ and of amount of solid phase. J. Biol. Chem. 1942, 143, 703-710.

29. Pan, H. B.; Darvell, B. W., Solubility of hydroxyapatite by solid titration at $\mathrm{pH} 3-4$. Arch. Oral Biol. 2007, 52, 618-624.

30. Green, D.; Perry, R., Perry's Chemical Engineers' Handbook, Eighth Edition. McGraw-Hill Education: 2007.

31. Koutsoukos, P. G. Current knowledge of calcium phosphate chemistry and in particular solid surface-water interface interactions, In Proceedings of the Second International Conference on Phosphorus Recovery for Recycling from Sewage and Animal Wastes, Institute of Chemical Engineering and High Temperature Chemical Processes, Univ. of Patras, 2000; pp 12-14.

32. Rice, G.; Barber, A.; O'Connor, A.; Stevens, G. W.; Kentish, S. E., Fouling of NF membrane by dairy ultrafiltration permeate. J. Membr. Sci. 2009, 330, 117-126.

33. Schäfer, A.; Fane, A. G.; Waite, T., Nanofiltration of natural organic matter: removal, fouling and the influence of multivalent ions. Desalin. 1998, 118, 109-122.

34. Kezia, K.; Lee, J.; Zisu, B.; Weeks, M.; Chen, G.; Gras, S.; Kentish, S., Crystallisation of minerals from concentrated saline dairy effluent. Water Res. 2016, 101, 300-308.

35. Amjad, Z. (Ed.), Calcium Phosphates in Biological and Industrial Systems. Springer US: 2013.

36. Chow, L. C.; Eanes, E. D., Octacalcium Phosphate. Karger: 2001; Vol. 18.

37. Tung, M.; Eidelman, N.; Sieck, B.; Brown, W., Octacalcium phosphate solubility product from 4 to 37 C. J. Res. Nat. Bur. Stand. 1988, 93, 613-624.

38. Mekmene, O.; Mekmene, F.; Gaucheron, Determination of calcium-binding constants of caseins, phosphoserine, citrate and pyrophosphate: A modelling approach using free calcium measurement. Food Chem. 2011, 127, 676-682.

39. Mekmene, O.; Mekmene, T.; Rouillon, S.; Quillard, P.; Pilet, J.-M.; Bouler, S.; Pezennec, F.; Gaucheron, Effects of citrate and $\mathrm{NaCl}$ on size, morphology, crystallinity and microstructure of calcium phosphates obtained from aqueous solutions at acidic or nearneutral pH. J. Dairy Res. 2012, 79, 238-248.

40. Sharma, V.; Johnsson, M.; Sallis, J.; Nancollas, G., Influence of citrate and phosphocitrate on the crystallization of octacalcium phosphate. Langmuir 1992, 8, 676-679.

41. Duputel, M.; Devau, N.; Brossard, M.; Jaillard, B.; Jones, D. L.; Hinsinger, P.; Gérard, F., Citrate adsorption can decrease soluble phosphate concentration in soils: Results of theoretical modeling. Appl. Geochem. 2013, 35, 120-131.

42. Holt, C., Calcium phosphate nanoclusters and their applications. United States Patent No. US 7517850 B2, 2009.

43. Holt, C.; Jenness, R., Interrelationships of constituents and partition of salts in milk samples from eight species. Comp. Biochem. Physiol. A: Mol. Integr. Physiol. 1984, 77, 275282. 
454 TABLE CAPTIONS

455 Table 1. The various forms of calcium phosphate that can form in aqueous solution and their 456 solubility at $25^{\circ} \mathrm{C}$ and neutral $\mathrm{pH}^{5}$.

457 Table 2. The $\mathrm{Ca} / \mathrm{P}$ ratio in the supernatant after 168 hours equilibration of $10 \mathrm{~g} / \mathrm{L}$ DCPD, with 458 a background concentration of $\mathrm{NaCl}$. Superscripts indicate samples that are not significantly 459 different $(\mathrm{p}>0.01)$.

460 Table 3. The Calcium and phosphorus concentrations in the supernatant after 168 hours 461 equilibration of $10 \mathrm{~g} / \mathrm{L}$ DCPD, with a background concentration of $\mathrm{NaCl}$ or sodium lactate.

462 Superscripts indicate samples that are not significantly different $(\mathrm{p}>0.01)$.

463 Table 4. The $\mathrm{Ca} / \mathrm{P}$ ratio in the supernatant after 168 hours equilibration of $10 \mathrm{~g} / \mathrm{L}$ DCPD, with 464 a background concentration of organic anions. Superscripts indicate samples that are not 465 significantly different $(\mathrm{p}>0.01)$.

466

467 
469 Figure 1. Schematic diagram of the end-point equilibrium technique.

470 Figure 2. (a) The concentration of calcium and (b) the calcium to phosphate ratio in the 471 supernatant after 168 hours of equilibration at $30^{\circ} \mathrm{C}$ of $10 \mathrm{~g} / \mathrm{L}$ DCPD, with a background 472 concentration of $\mathrm{NaCl}$ or lactose.

473 Figure 3 . The concentration of calcium in the supernatant after 168 hours of equilibration 474 of $10 \mathrm{~g} / \mathrm{L} \mathrm{DCPD}$, with a background concentration of $\mathrm{NaCl}$. Figure 4. (a) Activity coefficient of $\mathrm{Ca}^{2+}$ (b) Activity coefficient of orthophosphates 476 simulated using the Pitzer model within ASPEN Plus V8.6 at $25^{\circ} \mathrm{C}$. Concentrations of 477 calcium, phosphate and hydronium simulated were $10 \mathrm{mM}$.

478 Figure 5. Comparison of the experimental data for calcium and phosphorus concentrations 479 in the supernatant at $30^{\circ} \mathrm{C}$ with a simulation that assumes that DCPD is the only salt $(\mathrm{Ca} / \mathrm{P}=$ 480 1) and uses the activity coefficients determined from the Pitzer model and the solubility 481 constant from Table 1 at $25^{\circ} \mathrm{C}$.

482 Figure 6. Concentration of $\mathrm{Ca}^{2+}$ in the supernatant after 168 hours equilibration of $10 \mathrm{~g} / \mathrm{L}$ 483 DCPD and $1.25 \mathrm{~g} / \mathrm{L} \mathrm{DCPD}$ at $30^{\circ} \mathrm{C}$.

484 Figure 7. Concentration of calcium in the supernatant after 168 hours of equilibration of $48520 \mathrm{~g} / \mathrm{L}$ DCPD at $30^{\circ} \mathrm{C}$, with a background acid concentration (a) absolute concentrations (b) 486 concentrations relative to the nitric acid case.

487 Figure 8. (a) The concentration of $\mathrm{Ca}^{2+}$ in the supernatant with a background concentration 488 of an organic anion i.e. sodium lactate and trisodium citrate ( $\mathrm{pH} 7.0-8.7$ ) (b) The 489 concentration of $\mathrm{Ca}^{2+}$ in the supernatant with a background concentration of organic acid i.e. 
490 lactic acid and citric acid (pH 2.68 - 6.00) after 168 hours of equilibration of 10g/L DCPD.

491 The $\mathrm{NaCl}$ concentration is zero. Note the different $\mathrm{x}$-axis scales on the two graphs.

492 Figure 9. The calcium to phosphate ratio in the supernatant after 168 hours of equilibration 493 at $30^{\circ} \mathrm{C}$ of $10 \mathrm{~g} / \mathrm{L}$ DCPD, with a background concentration of lactic acid, trisodium citrate or 494 sodium lactate.

495 Figure 10. Concentration of calcium and phosphorous in the supernatant after 168 hours of 496 equilibration at $30^{\circ} \mathrm{C}$ of $10 \mathrm{~g} / \mathrm{L}$ in $10 \mathrm{mM}$ lactic acid, with a background concentration of $497 \mathrm{NaCl}$

498 
Table 1

\begin{tabular}{|c|c|c|c|c|}
\hline $\begin{array}{l}\mathrm{Ca} / \mathrm{P} \\
\mathrm{mol} \\
\text { ratio }\end{array}$ & Compound & Formula & $\begin{array}{l}\text { Solubility } \\
\qquad 25^{\circ} \mathrm{C} \\
-\log (\mathrm{Ksp})\end{array}$ & $\begin{array}{l}\text { pH* } \\
25^{\circ} \mathrm{C}\end{array}$ \\
\hline 0.5 & $\begin{array}{l}\text { Monocalcium phosphate } \\
\text { monohydrate (MCPM) }\end{array}$ & $\mathrm{Ca}\left(\mathrm{H}_{2} \mathrm{PO}_{4}\right)_{2} \cdot \mathrm{H}_{2} \mathrm{O}$ & 1.14 & $0.0-2.0$ \\
\hline 1.0 & $\begin{array}{l}\text { Dicalcium phosphate dihydrate } \\
\text { (DCPD, brushite) }\end{array}$ & $\mathrm{CaHPO}_{4} .2 \mathrm{H}_{2} \mathrm{O}$ & 6.59 & $2.0-6.0$ \\
\hline 1.3 & Octacalcium phosphate (OCP) & 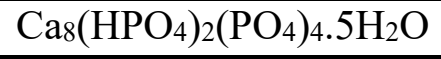 & 96.6 & $5.5-7.0$ \\
\hline $1.2-2.2$ & $\begin{array}{l}\text { Amorphous calcium phosphates } \\
\text { (ACP) }\end{array}$ & $\begin{array}{c}\mathrm{Ca}_{\mathrm{x}} \mathrm{H}_{\mathrm{y}}\left(\mathrm{PO}_{4}\right)_{\mathrm{z}} \cdot \mathrm{nH}_{2} \mathrm{O} \\
\mathrm{n}=3-4.5\end{array}$ & $* * *$ & $5.0-12.0$ \\
\hline $1.5-1.7$ & $\begin{array}{l}\text { Calcium deficient hydroxyapatite } \\
\text { (CDHA) }\end{array}$ & $\begin{array}{c}\mathrm{Ca}_{10-\mathrm{x}}\left(\mathrm{HPO}_{4}\right)_{\mathrm{x}}\left(\mathrm{PO}_{4}\right)_{6-} \\
\mathrm{x}(\mathrm{OH})_{2-\mathrm{x}} \\
(0<\mathrm{x}<1)\end{array}$ & $\approx 85$ & $6.5-9.5$ \\
\hline 1.7 & Hydroxyapatite (HAP) & $\mathrm{Ca}_{10}\left(\mathrm{PO}_{4}\right)_{6}(\mathrm{OH})_{2}$ & 116.8 & $9.5-12.0$ \\
\hline
\end{tabular}

* $\mathrm{pH}$ where the solid can exist in aqueous solution at room temperature.

$501 * * *$ cannot be precisely measured, in acidic buffer $\mathrm{ACP}<\mathrm{CDHA}<\mathrm{HAP}$. 
503 Table 2

\begin{tabular}{|ccccc|} 
& $0 \mathrm{~g} / \mathrm{L} \mathrm{NaCl}$ & $10 \mathrm{~g} / \mathrm{L} \mathrm{NaCl}$ & $100 \mathrm{~g} / \mathrm{L} \mathrm{NaCl}$ & $300 \mathrm{~g} / \mathrm{L} \mathrm{NaCl}$ \\
\hline $10^{\circ} \mathrm{C}$ & $0.52 \pm 0.06^{\mathrm{a}}$ & $0.74 \pm 0.04^{\mathrm{b}}$ & $0.74 \pm 0.03^{\mathrm{b}}$ & $0.77 \pm 0.01^{\mathrm{b}}$ \\
& & & & \\
\hline $30^{\circ} \mathrm{C}$ & $0.54 \pm 0.03^{\mathrm{a}}$ & $0.72 \pm 0.01^{\mathrm{b}}$ & $0.77 \pm 0.02^{\mathrm{b}}$ & $0.72 \pm 0.04^{\mathrm{b}}$ \\
\hline $50^{\circ} \mathrm{C}$ & $0.45 \pm 0.03^{\mathrm{c}}$ & $0.46 \pm 0.01^{\mathrm{c}}$ & $0.44 \pm 0.02^{\mathrm{c}}$ & $0.46 \pm 0.04^{\mathrm{c}}$ \\
\hline
\end{tabular}

504

505 
506 Table 3

\begin{tabular}{|ccccc|}
\hline \multicolumn{2}{|c}{ Calcium $(\mathrm{mM})$} & \multicolumn{2}{c|}{ Phosphorus $(\mathrm{mM})$} \\
\hline & $\mathbf{1 7 0} \mathbf{~} \mathbf{~ M ~ N a C l}$ & $\mathbf{1 0 0} \mathbf{~} \mathbf{M}$ NaLactate & $\mathbf{1 7 0} \mathbf{~} \mathbf{M} \mathbf{~ N a C l}$ & $\mathbf{1 0 0} \mathbf{~ m M}$ NaLactate \\
\hline $10^{\circ} \mathrm{C}$ & $1.97 \pm 0.13$ & $1.99 \pm 0.22$ & $2.65 \pm 0.15$ & $2.46 \pm 0.05$ \\
& & & & \\
\hline $30^{\circ} \mathrm{C}$ & $1.96 \pm 0.11$ & $1.87 \pm 0.10$ & $2.67 \pm 0.06$ & $2.71 \pm 0.03$ \\
\hline
\end{tabular}

507

508 
509 Table 4

\begin{tabular}{|c|c|c|c|c|c|}
\hline $10^{\circ} \mathrm{C}$ & $30^{\circ} \mathrm{C}$ & $50^{\circ} \mathrm{C}$ & $10^{\circ} \mathrm{C}$ & $30^{\circ} \mathrm{C}$ & $50^{\circ} \mathrm{C}$ \\
\hline \multicolumn{3}{|c|}{ Sodium Lactate } & \multicolumn{3}{|c|}{ Trisodium Citrate } \\
\hline $0.66 \pm 0.04^{a}$ & $0.61 \pm 0.04^{\mathrm{a}}$ & $0.45 \pm 0.01^{b}$ & $0.84 \pm 0.06^{\mathrm{c}}$ & $0.81 \pm 0.03^{c}$ & $0.27 \pm 0.04^{\mathrm{d}}$ \\
\hline \multicolumn{3}{|c|}{ Lactic Acid } & \multicolumn{3}{|c|}{ Citric Acid } \\
\hline $0.96 \pm 0.08^{e}$ & $1.04 \pm 0.04^{\mathrm{f}}$ & $0.92 \pm 0.03^{\mathrm{e}}$ & $0.88 \pm 0.07^{\mathrm{g}}$ & $0.78 \pm 0.04^{\mathrm{c}}$ & $0.64 \pm 0.03^{a}$ \\
\hline
\end{tabular}

510

511

512

513 


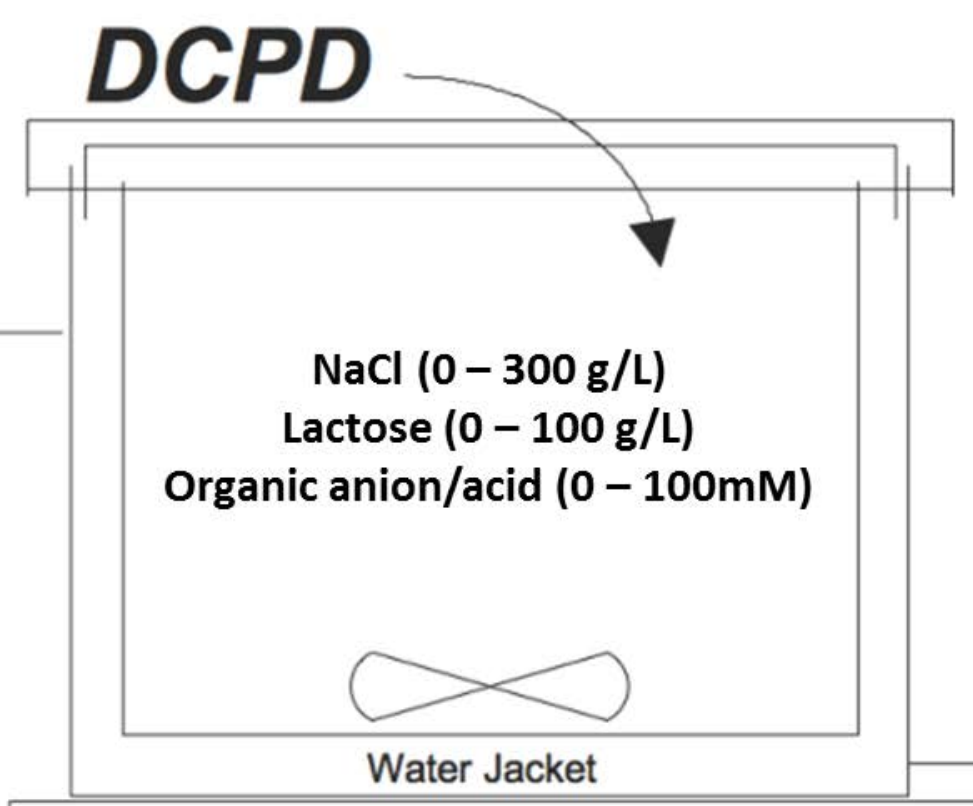

\section{Stirrer Plate (250 rpm)}




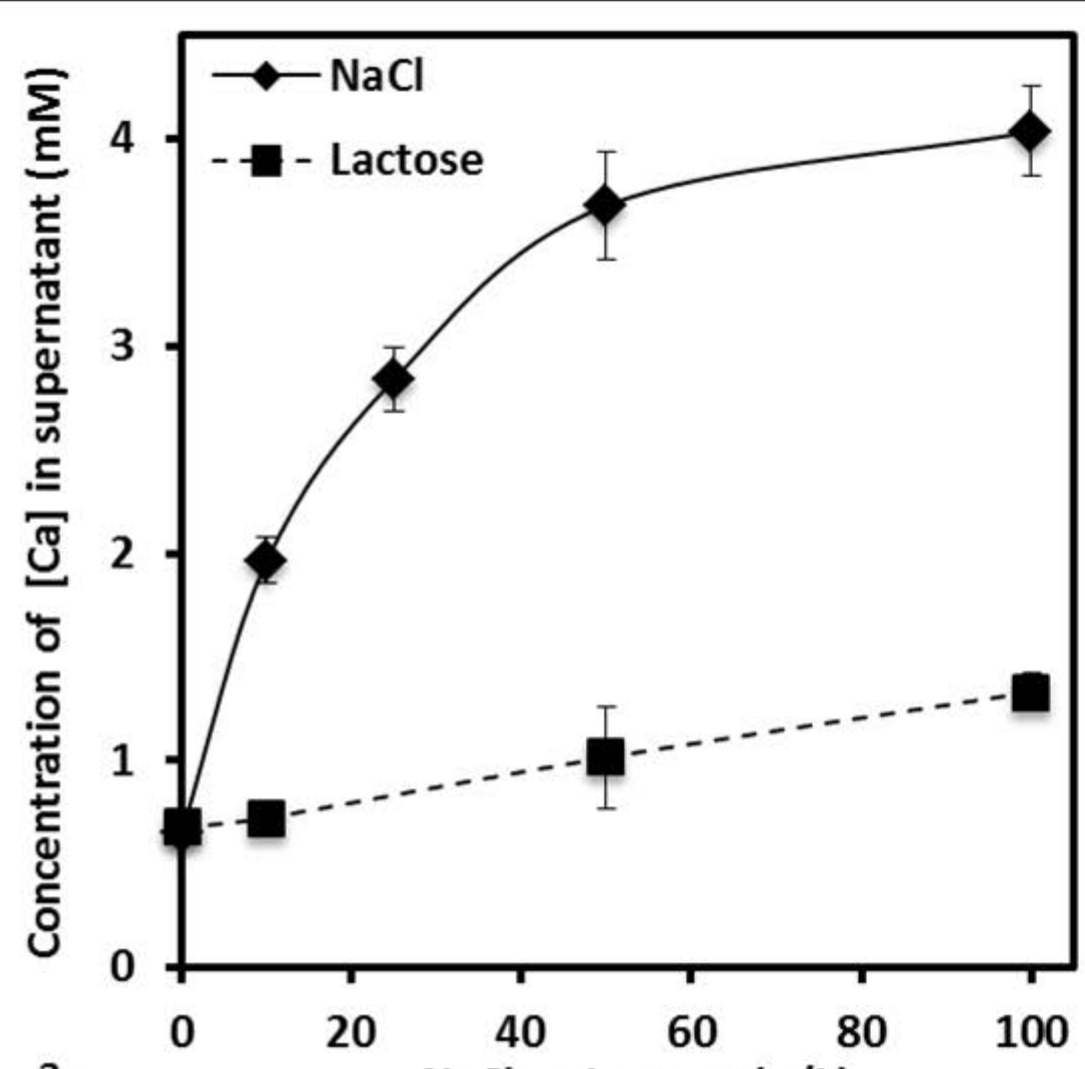

a. $\mathrm{NaCl}$ or Lactose $(\mathrm{g} / \mathrm{L})$ (0- $1.7 \mathrm{M} \mathrm{NaCl}$ or $0-0.3 \mathrm{M}$ Lactose)

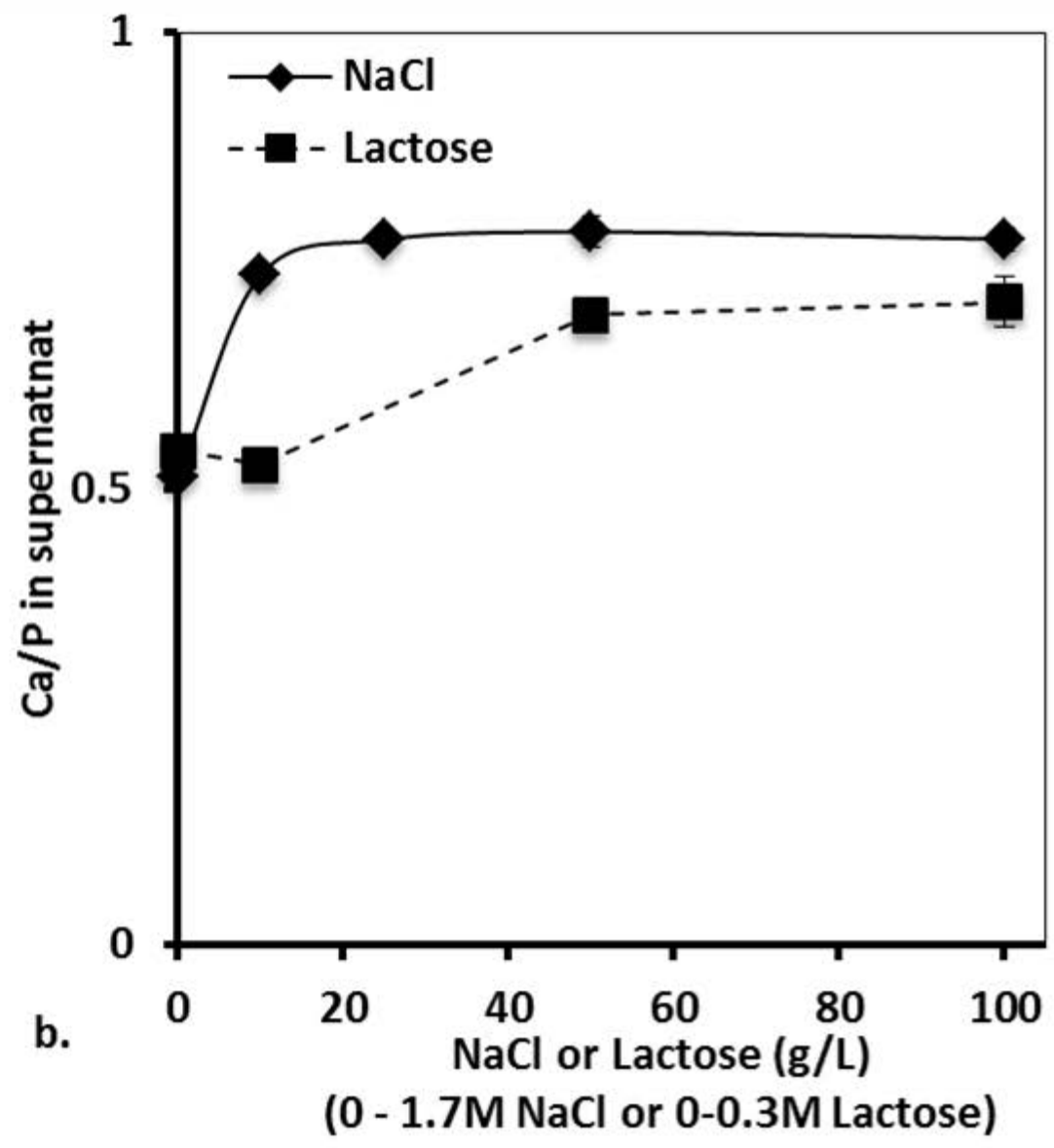




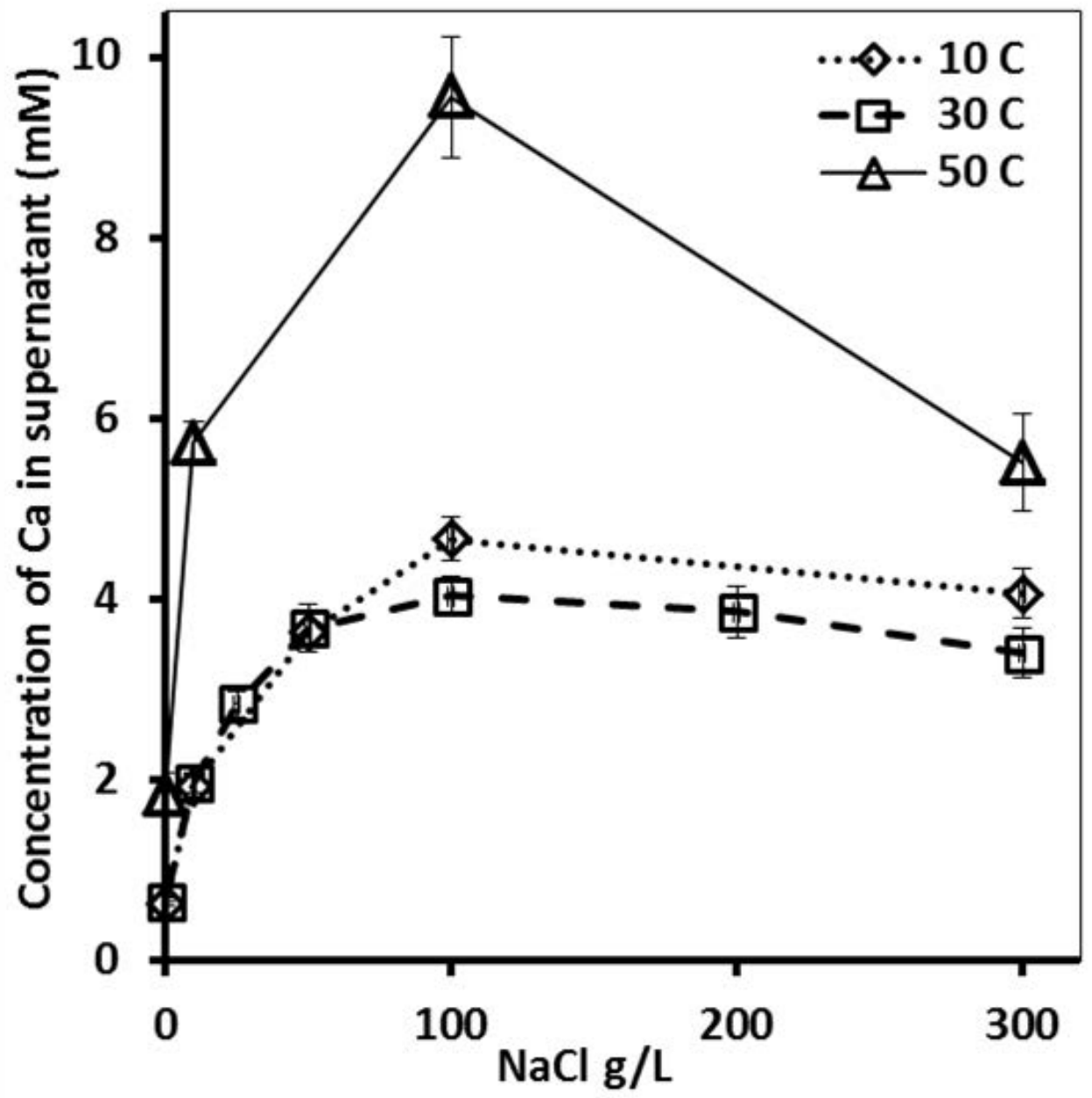



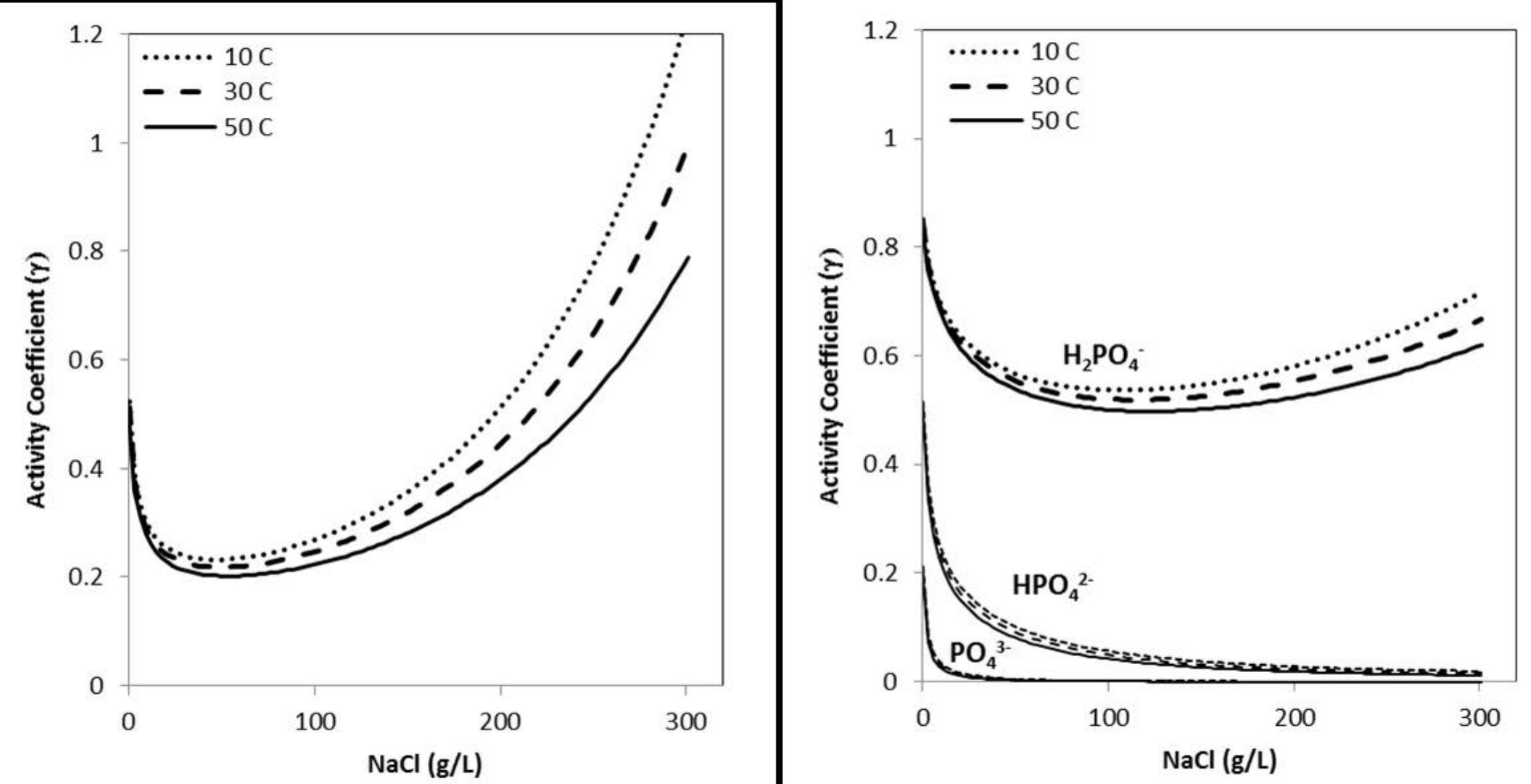


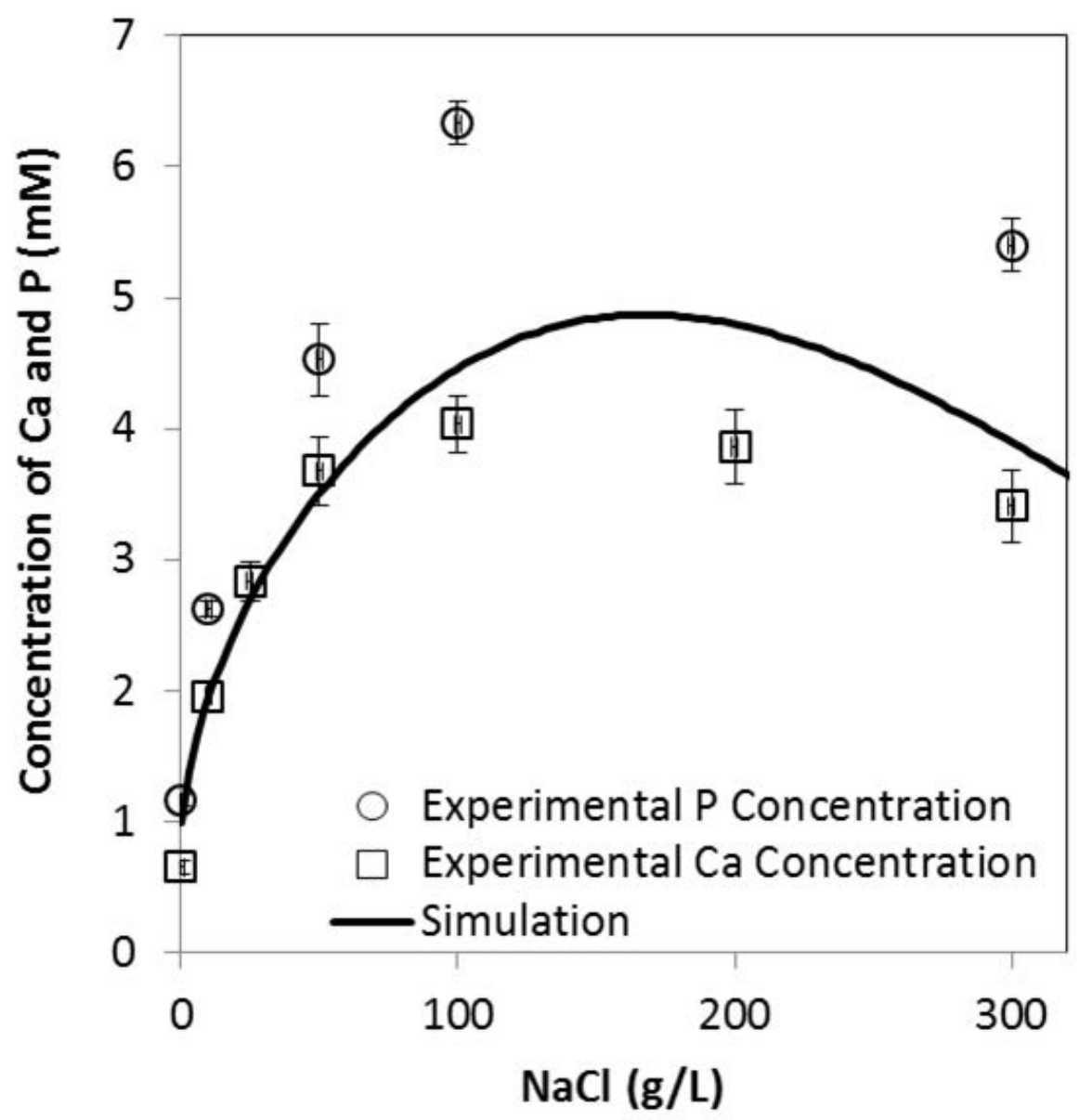




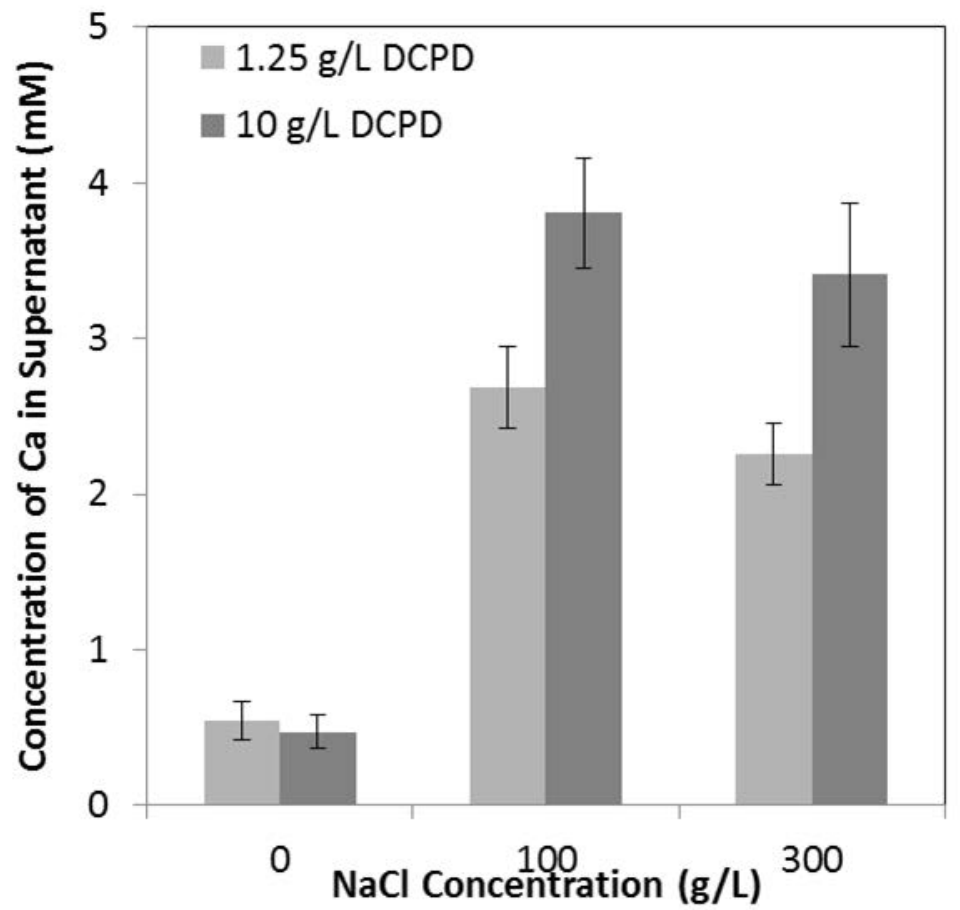




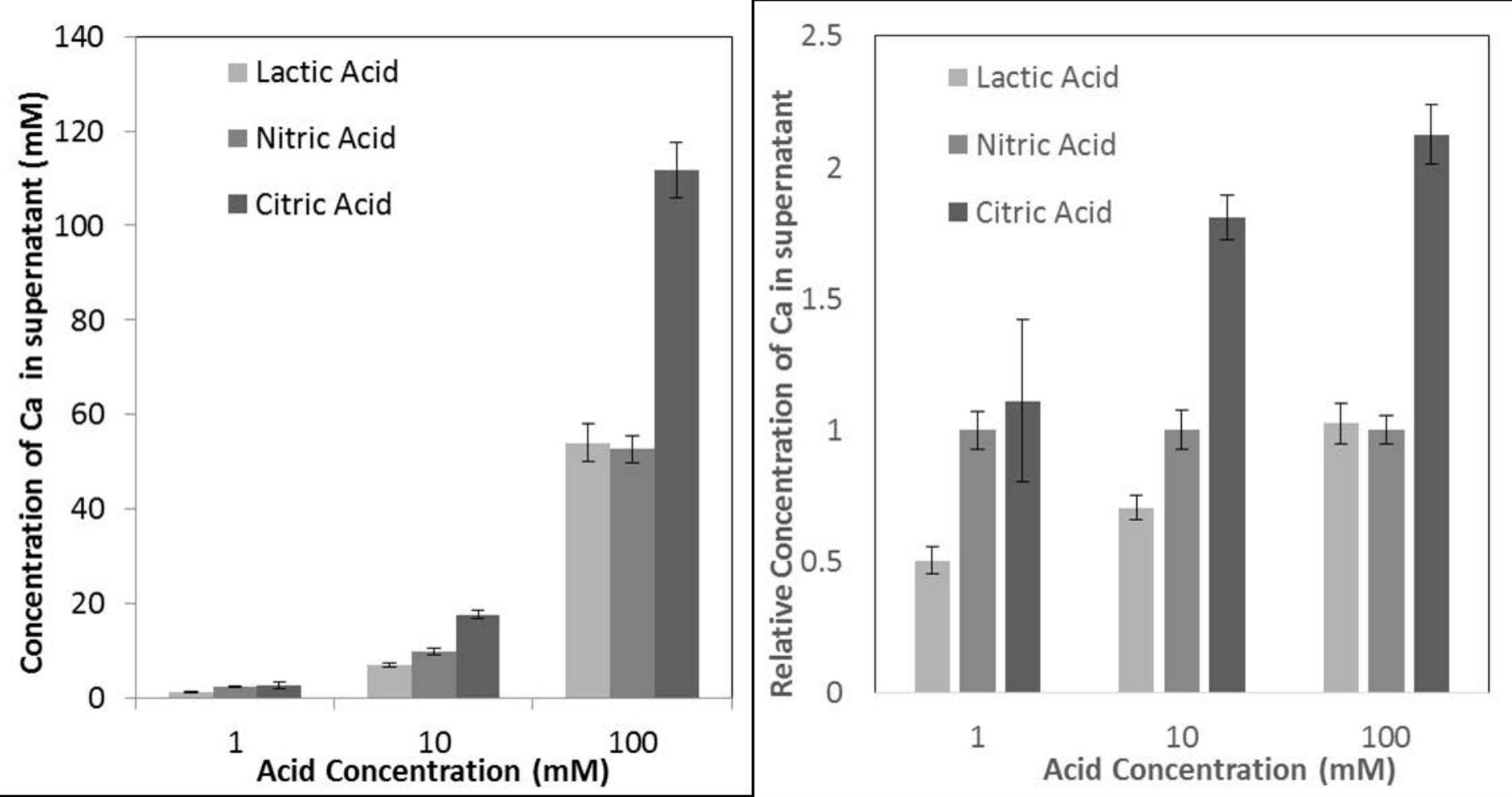




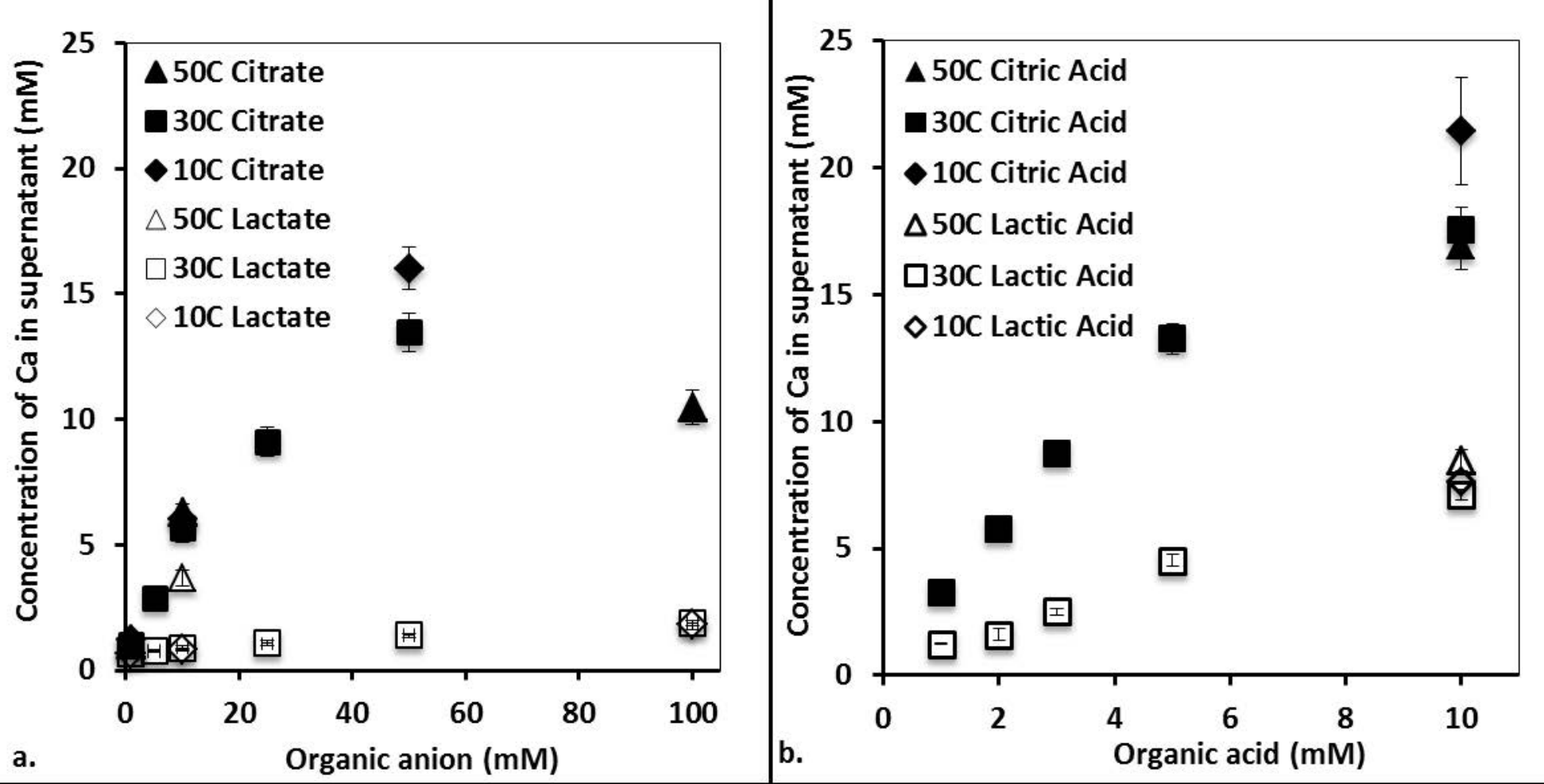




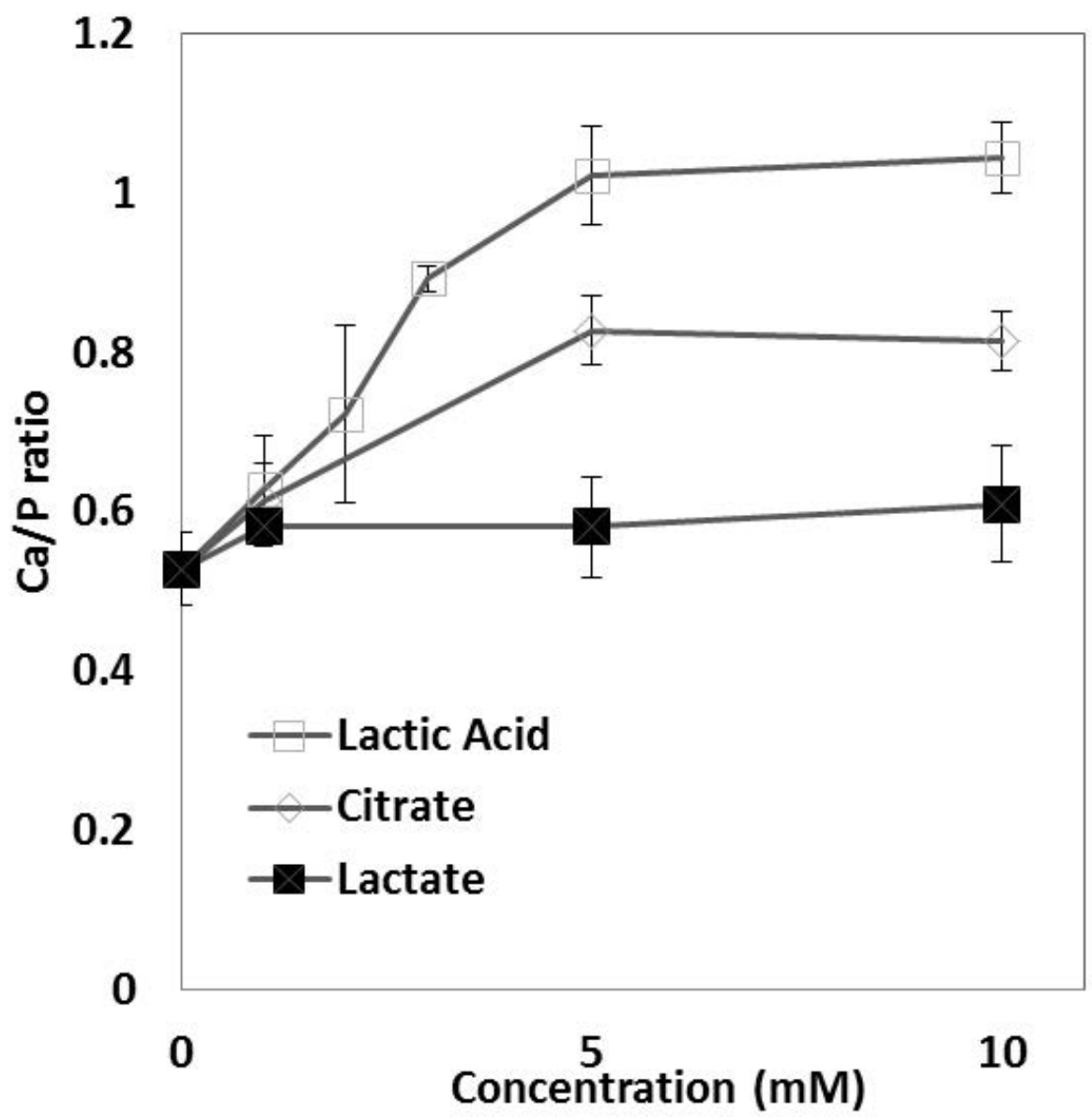




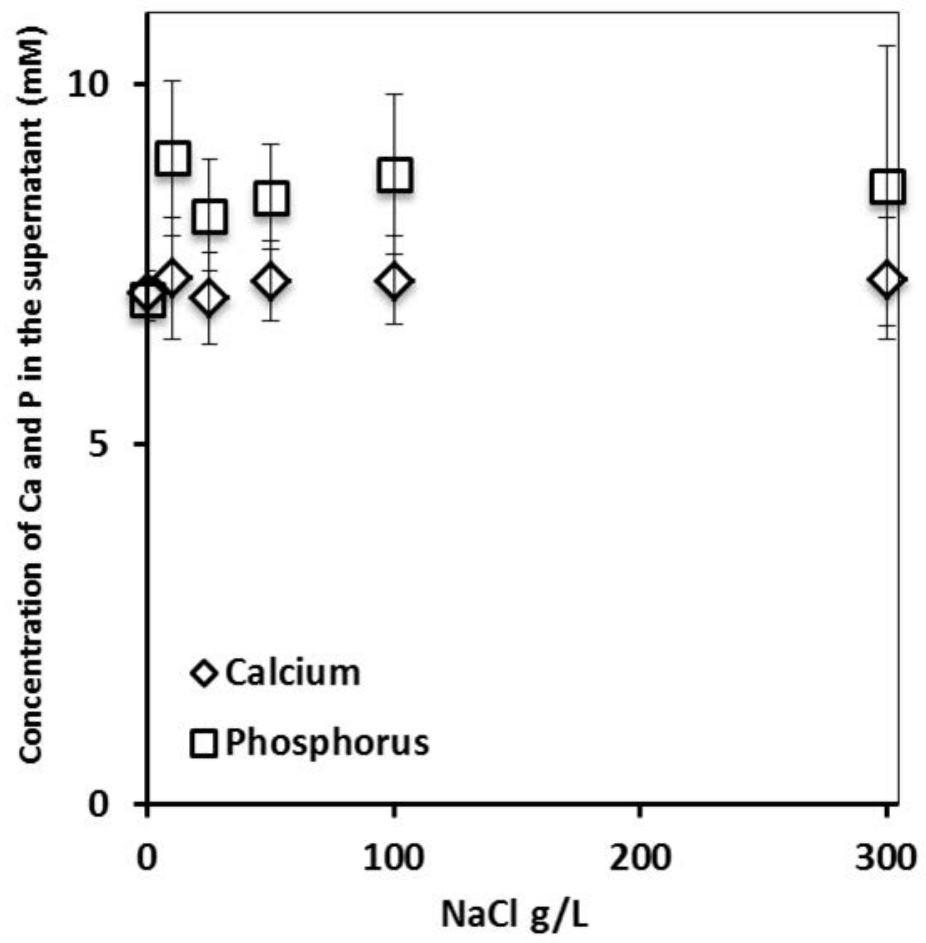

